\title{
Solar Pond Performance Enhances Nonconventional Water Resource Availability
}

\author{
Mohamed Nower, Ashraf Elashaal, El-serafy S.
}

\begin{abstract}
In the context of utilizing solar ponds, this research was commenced to enhance their performance so as to rely on them as a nonconventional water resources. Primarily, literature was reviewed in the field of solar ponds. The technique can be used to develop the energy needed for pumping, lifting, collecting or treating water. The agricultural sector users claim that water and energy face problems of environmental degradation due to resources scarcity. This research paper, data was gathered and analyzed, in terms of solar pond parameters such as depth of the upper gradient, shading effect, storage zones, daylight hours, ground temperature and covered insulation for different climate zones so as for different latitudes. The analyzed results indicated that solar ponds possess high potential in arid and semi-arid climates similar to Fayoum governorate, where it is distinguished by its ability to collect heat which can be utilized in different applications. The application cover desalination, electric power generation, salt purification, food and fishing industries. The solar pond technique utilized in many countries to act as the backbone for sustainable development in arid and semi-arid zones such as Victoria desert in Australia.
\end{abstract}

Keywords: Solar Pond, Desalination, nonconventional water resources

\section{INTRODUCTION}

Water is an essential human need to attain sustainable development. Accordingly, human race is after any nonconventional resource due to water scarcity.

In the last decades, it was obvious that solar ponds could be utilized as a nonconventional water resource. A solar pond is a saltwater pool, which stores solar energy. The saltwater forms a salinity gradient "halocline", where low-salinity floats on top and high salinity underlies it. The layers of salty water increase in concentration and density, as depth increases. Deeper than a certain depth, the solution becomes uniformly distributed, in terms of salt concentration.

Many researchers investigated the possibility of enhancing the solar ponds performance to rely on it as nonconventional water resource. Among them are the following:

- [1] stated that global projections which indicated that

Revised Manuscript Received on April 11, 2020.

* Correspondence Author

Mohamed Nower*, Associate Researcher, National water research center, Cairo, Egypt. Email: nower2020@gmail.com

Ashraf Elashaal, professor Emeritus, National water research center, Cairo, Egypt. Email: aaselashaal@yahoo.com

El-serafy S, Professor and head of the hydraulics and engineering department of Ain Shams University, Cairo, Egypt. Email: sonia_elserafy@eng.asu.edu.eg

(C) The Authors. Published by Blue Eyes Intelligence Engineering and Sciences Publication (BEIESP). This is an open access article under the CC BY-NC-ND license (http://creativecommons.org/licenses/by-nc-nd/4.0/) freshwater demand will increase drastically, over the next decades under the pressure of increasing population, urbanization and climate change.

- [2] documented that energy is needed to pump or lift or collect or treat water. The agricultural sector users claim that water and energy face problems of environmental degradation due to resources scarcity.

- [3] signposted that renewable energy is important in decreasing gas emissions. Accordingly, solar systems have minimum negative impacts on the environment, which stresses on the need of modeling solar ponds as a source of renewable energy; Figure (1). It designates layer modeling in solar ponds.

Accordingly, this research was initiated with the objective of improving their literature performance to bank on as a nonconventional water resource.

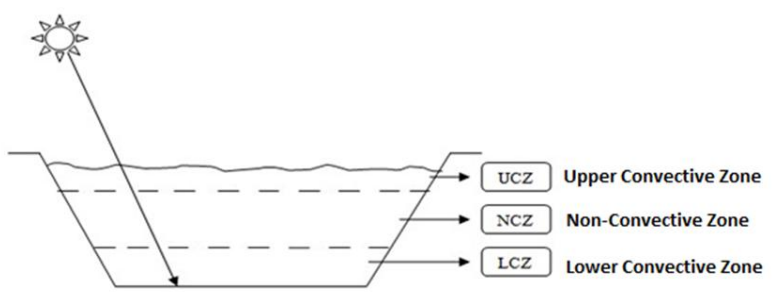

Fig. 1. Solar Pond layers modeling [3]

\section{STUDY AREA}

Several study areas can be carried out solar pond technique to for specific areas in Egypt like Alexandria governorate, El_Gharbia governorate, Dakahlia governorate, North Sinai governorate, El_Fayoum governorate and Siwa Oasis in Matrouh governorate. These areas are salt producers with a high thermal potential; Figure (2). which signposts salt factories in Egypt.

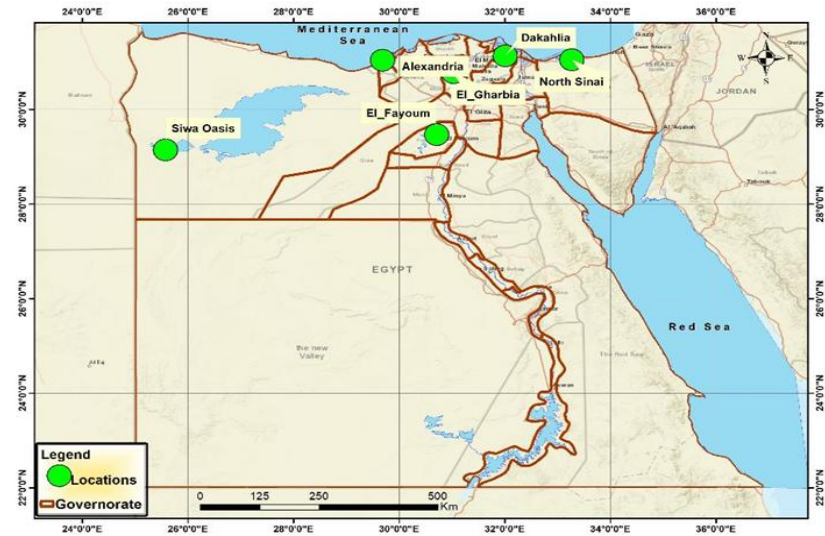

Fig. 2. Salt factories locations in Egypt

Published By:

Blue Eyes Intelligence Engineering \& Sciences Publication

(C) Convriaht: All riahts reserved. 


\section{DATA ASSEMBLY}

During the survey, data was deduced, and assembled from the literature, as follows:

- GEO-CRADLE project for Solar Radiation Atlas [4]

- Egypt wind atlas [5].

- Climatological parameters data from NASA [6]

- Equations of solar pond [3]

\section{DATA PROCESSING}

The assembled data from the above literature was scrutinized and processed, from which the researcher deduced the following information:

\section{A. GEO-CRADLE PROJECT FOR SOLAR RADIATION ATLAS}

This source encompassed the direct normal radiation (DNR) that was calculated based on the monthly DNR of 1999-2013 (i.e. 15-year record). Accordingly, the researcher achieved the following:

- The solar energy potential for efficient solar pond at a 5 $\mathrm{km}$ resolution was quantified.

- Solar maps were utilized and the climatological radiation, from EUMETSAT's satellite [4], was obtained and processed Figure (3) and Figure (4).

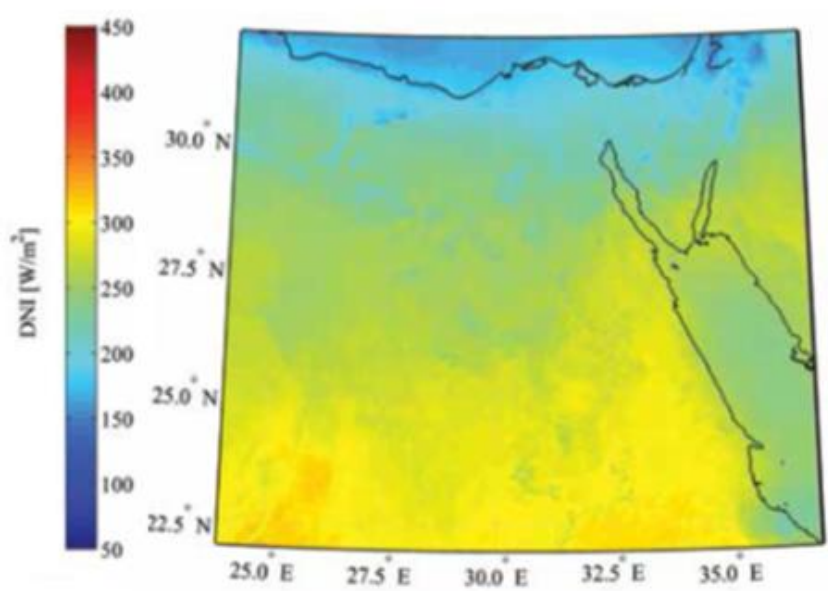

Fig. 3. Direct normal irradiance in January representing for winter season [4]

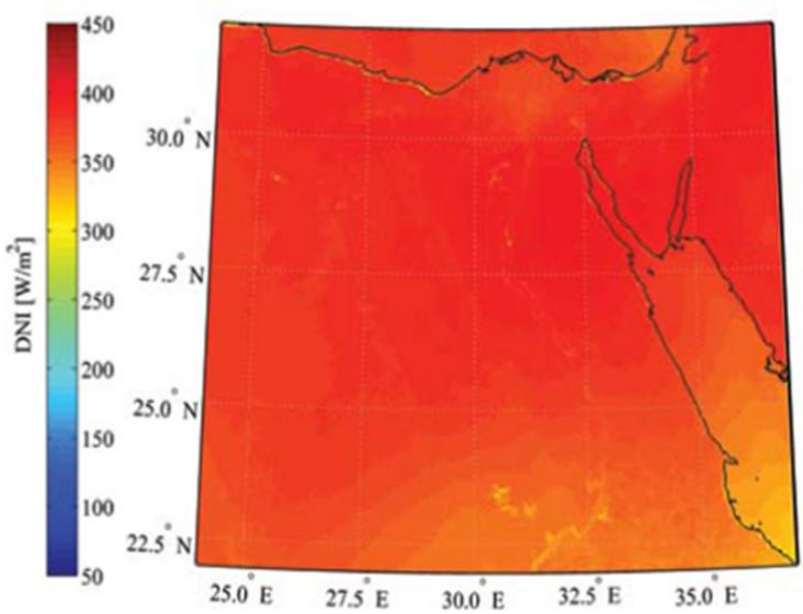

Fig. 4. Direct normal irradiance in June representing for summer season [4]

\section{B. WIND ATLAS OF EGYPT}

This source encompassed data of more than twenty-year wind resource program in Egypt. Accordingly, the researcher achieved the following:

- Wind atlas data sets were utilized for evaluating the solar pond installations.

- Wind climate of Egypt was determined from stations covered all over Egypt [5,6]; Figure (5).

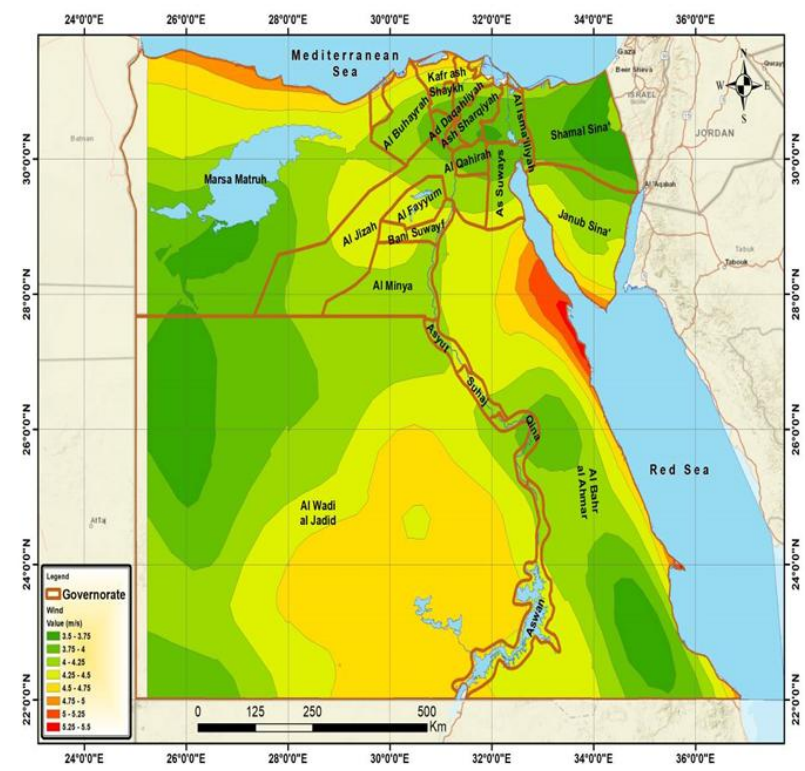

Fig. 5. Wind speed in Egypt

\section{CLIMATOLOGICAL PARAMETERS DATA FROM NASA}

This source encompassed records of average data; direct solar radiation horizontal, air temperature, wind speed, relative humidity, and atmospheric pressure for more than twenty years [6]. Accordingly, the researcher extracted the following:

- Direct normal radiation

- Daylight hours

- Maximum wind speed

- Wind speed at $10 \mathrm{~m}$

- Relative humidity

These are presenting on Figure (6) to Figure (10).

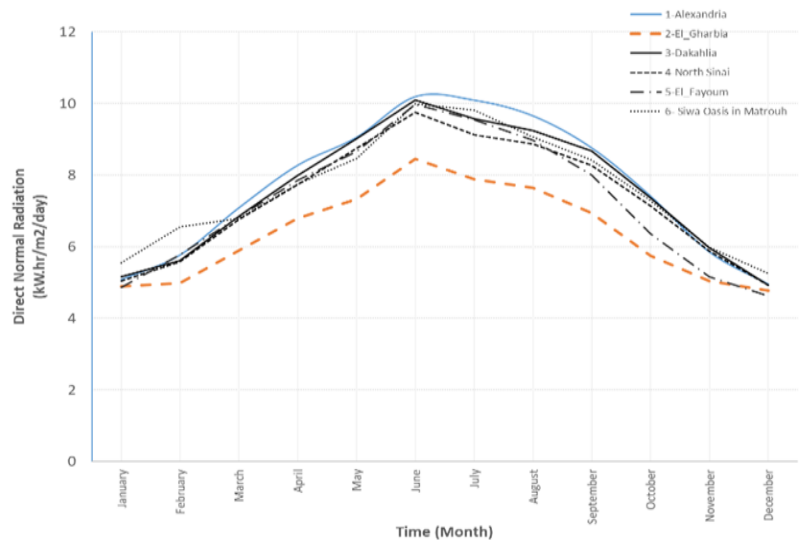

Fig. 6. Direct normal radiation

Published By:

Blue Eyes Intelligence Engineering \& Sciences Publication

(c) Copvriaht: All riahts reserved.

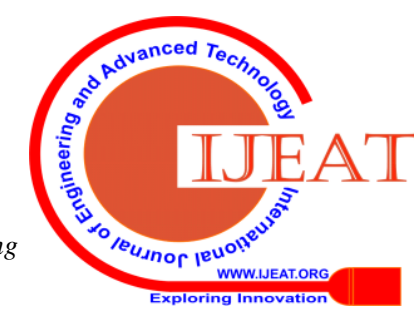




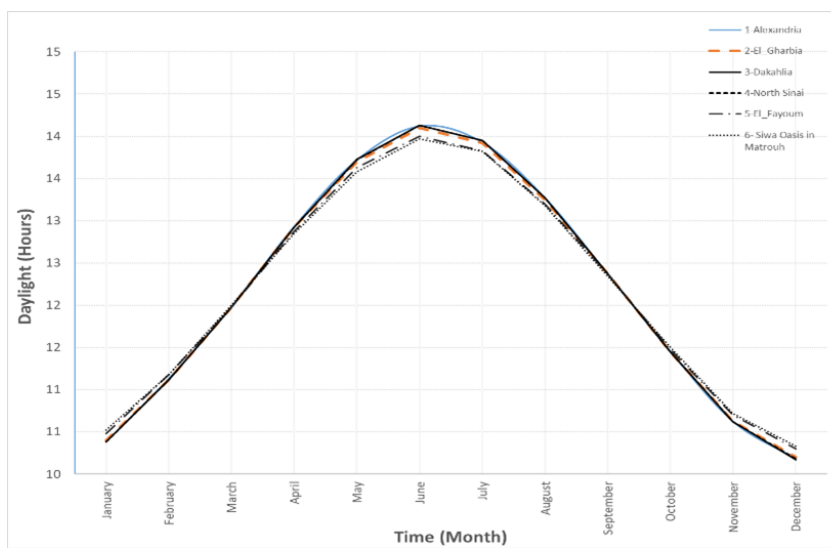

Fig. 7. Daylight hours

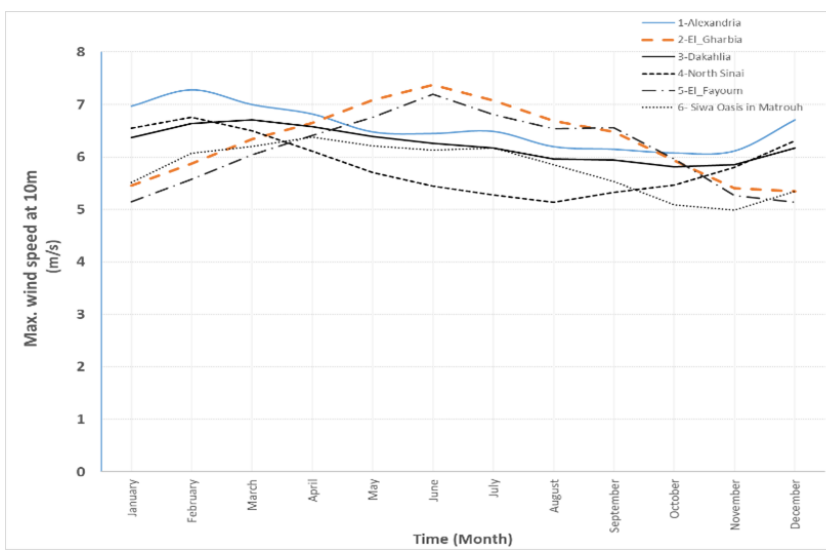

Fig. 8. Maximum wind speed

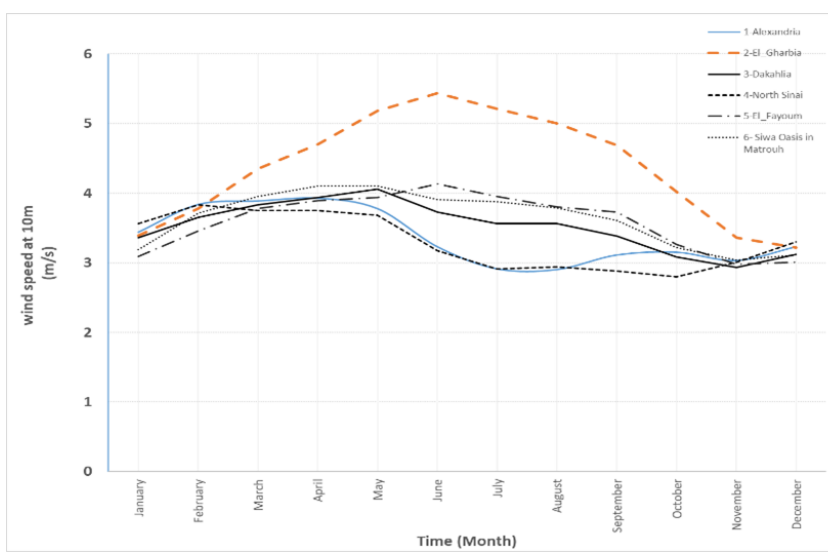

Fig. 9. Wind speed

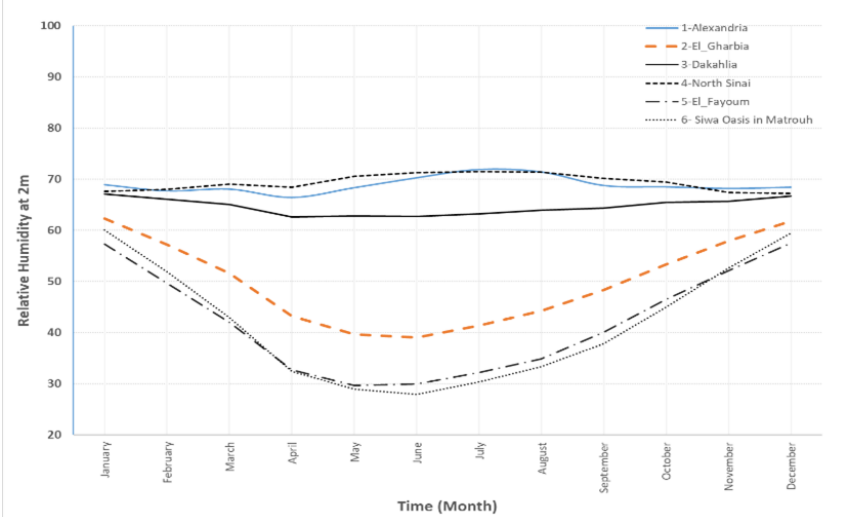

Fig. 10. Relative humidity

VI. MODEL DESCRIPTION

Heat simulation might be presented as convective or radiation or evaporation or sides loss [4]. Figure (11) designates the heat balance in pond upper zone, where the steady state is described, as follows:

$$
\rho_{u} C_{p u} A_{u} X_{u} \frac{d T_{u}}{d t}=Q_{r u}+Q_{u b}-Q_{u c}-Q_{u r}-Q_{u e}-Q_{w}
$$

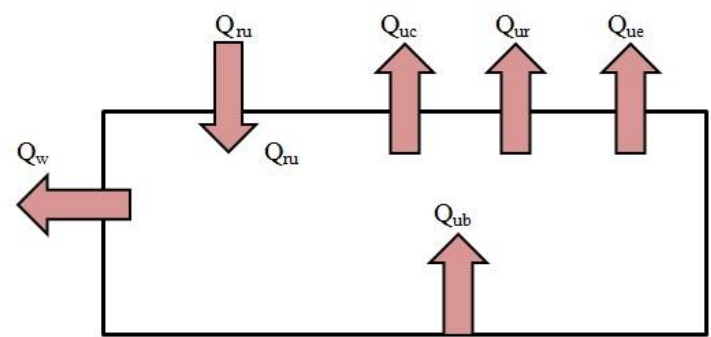

Fig. 11. Heat balance in pond upper zone

The left hand side of equation (1) defines the heat accumulated in the upper zone. The right hand side of equation (1) denotes the heat loss "Qw" via pond walls.

Qw was assumed to be 0 , as the walls are insulated [3]; Figure (12). It shows the heat balance in the storage zone, where equation (1) is rewritten as follows:

$\rho_{u} C_{p u} A_{u} X_{u} \frac{d T_{u}}{d t}=A_{u}\left[\begin{array}{l}Q_{r u}+\frac{\left[T_{s}-T_{u}\right]}{\frac{1}{h_{1}}+\frac{X_{N C Z}}{K_{w}}+\frac{1}{h_{2}}}-\left[(5.7+3.8 v)\left(T_{u}-T_{a}\right)\right] \\ -4.708 \times 10^{-8}\left(T_{u}^{4}-\left(0.0552\left(T_{a}\right)^{1.5}\right)^{4}\right) \\ -\frac{\left[\lambda h_{c}\left(P_{u}-P_{a}\right)\right]}{1.6 C_{s} P_{a t m}}\end{array}\right]$

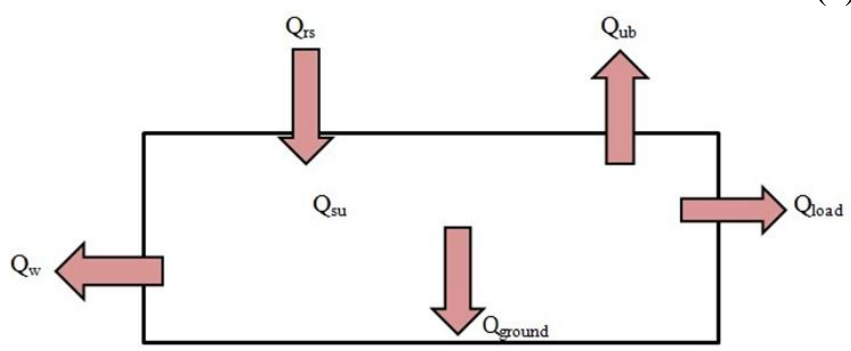

Fig. 12. Heat balance in the storage zone

Accordingly, the storage steady state is written as follows:

$$
\rho_{l} C_{p l} A_{l} X_{l} \frac{d T_{s}}{d t}=Q_{r s}-Q_{u b}-Q_{g r o u n d}-Q_{\text {load }}-Q_{w}
$$

At a no load scenario, Qload is 0. This corresponds to initial warming of the pond. Also, at $\mathrm{Qw}=0$, equation (3) is rewritten as:

$$
\rho_{l} C_{p l} A_{l} X_{l} l \frac{d T_{s}}{d t}=A_{l}\left[Q_{r s}-\frac{\left[T_{s}-T_{u}\right]}{\frac{1}{h_{1}}+\frac{X_{N C Z}}{K_{w}}+\frac{1}{h_{2}}}\right]-\frac{A_{b}\left[T_{s}-T_{g}\right]}{\frac{1}{h_{3}}+\frac{X_{g}}{K_{g}}+\frac{1}{h_{4} \cdots .}}
$$

\section{RESULTS DISCUSSION AND ANALYSIS}

Based on the site visits, scrutinized literature, processed data and modelling, results are follows:

- Egypt has a good potential for solar ponds, where the deeper the gradient, the less the radiation entering the pond.

\section{Published By:}

Blue Eyes Intelligence Engineering

\& Sciences Publication

(C) Cobvriaht: All riahts reserved.

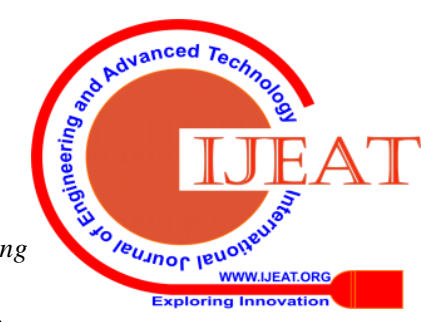


- At a gradient layer of $1 \mathrm{~m}$ depth, $36 \%$ of the radiation is available.

- At a depth of $2 \mathrm{~m}$, radiation will be reduced to $30 \%$.

- Irradiation data for the different locations is given on Figure (13).

- Alexandria has highest radiation in June of 36.72 $\mathrm{MJ} / \mathrm{m}^{2} /$ day.

- Fayoum has lowest radiation in December of 16.67 $\mathrm{MJ} / \mathrm{m}^{2} /$ day.

- Alexandria has highest Annual radiation of 27.66 $\mathrm{MJ} / \mathrm{m}^{2} /$ day.

- El_Gharbia radiation is $22.93 \mathrm{MJ} / \mathrm{m}^{2} /$ day.

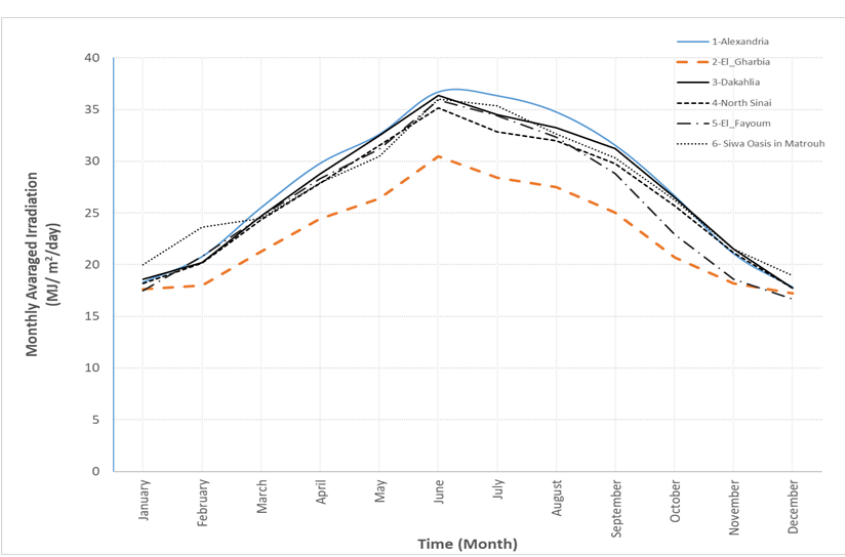

Fig. 13. Irradiation data

Equations (2) and (4) were solved by implementing the primary values of the temperatures Tu and Ts. These values vary by pond location.

The constants in the model are, as follows:

- $\rho_{\mathrm{u}}=1000 \mathrm{~kg} / \mathrm{m}^{3}$

- $\rho_{\mathrm{l}}=1200 \mathrm{~kg} / \mathrm{m}^{3}$

- $\mathrm{C}_{\mathrm{pu}}=4180 \mathrm{~J} / \mathrm{kg} \mathrm{K}$

- $\mathrm{C}_{\mathrm{pl}}=3300 \mathrm{~J} / \mathrm{kg} \mathrm{K}$

- $\mathrm{A}_{\mathrm{u}}=\mathrm{Al}=\mathrm{Ab}=1 \mathrm{~m}^{2}$

- $\mathrm{h}_{1}=56.58 \mathrm{~W} / \mathrm{m}^{2} \mathrm{~K}$

- $\mathrm{h}_{2}=48.279 \mathrm{~W} / \mathrm{m}^{2} \mathrm{~K}$

- $\mathrm{h}_{3}=78.12 \mathrm{~W} / \mathrm{m}^{2} \mathrm{~K}$

- $\mathrm{h}_{4}=185 \mathrm{~W} / \mathrm{m}^{2} \mathrm{~K}$

- $\mathrm{k}_{\mathrm{w}}=0.596 \mathrm{~W} / \mathrm{m} \mathrm{K}$

- $\mathrm{Tg}=23^{\circ} \mathrm{C}$

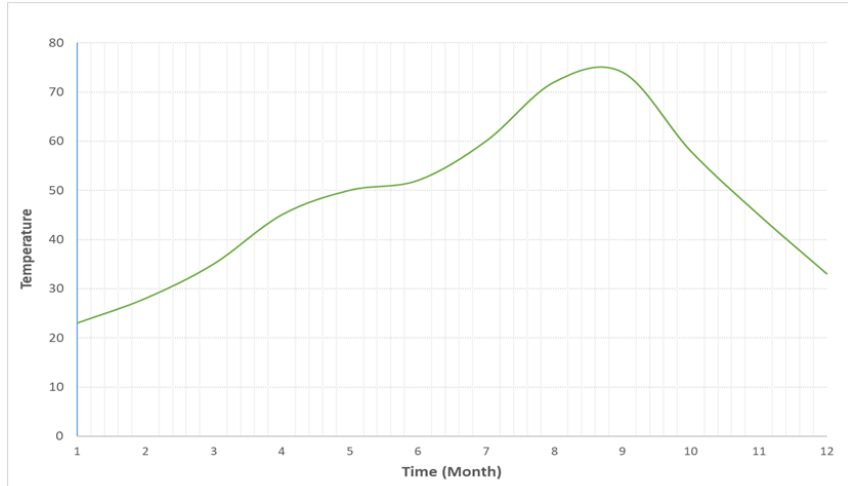

Fig. 14. Storage Zone Temperature in Fayoum

Figure (14), shows the storage zone temperature at different areas, from which the following was clear:

- Maximum temperatures in June to September ranged between $71^{\circ} \mathrm{C}$ and $74^{\circ} \mathrm{C}$
- The minimum temperatures in December and January ranged between $23^{\circ} \mathrm{C}$ to $28^{\circ} \mathrm{C}$

- The Storage Zone (LCZ) temperature is $70^{\circ} \mathrm{C}$

\section{CONCLUSIONS AND RECOMMENDATIONS}

Based on the obtained results, the following conclusions and recommendations were deduced:

- Solar pond technique is environment friendly when applied in power generation and desalination

- Solar pond technique can be utilized to cover the urgent demand of energy when the required boundary conditions such as Direct solar irradiation, temperature, wind and relative humidity are satisfied

- Solar Pond technique can provide cheap energy source which can be utilized in desalination of sea and brackish water as a nonconventional water resources

- Different areas of Egypt have been examined for solar pond potential like Fayoum governorate possess a maximum irradiance of $26.03 \mathrm{MJ} / \mathrm{m}^{2} /$ day while El_Gharbia governorate has irradiance of 22.93 $\mathrm{MJ} / \mathrm{m}^{2} /$ day.

\section{REFERENCES}

1. H. Hoff, "Understanding the nexus: Background paper for the Bonn2011 Conference", 2011.

2. O. e. Dubois, The state of the world's land and water resources for food and agriculture: managing systems at risk., Earthscan, 2011.

3. Qiblawey, H. M., \& Banat, F., "Solar thermal desalination technologies", Desalination, Elsevier, 2008, pp. 633-644.

4. P.Kosmopoulos, et. al. "The Solar Atlas of Egypt," 2018. [Online]. Available: http://www.nrea.gov.eg.

5. Mortensen, N. G., Said, U. S., \& Badger, J., Wind atlas for Egypt, 3rd Middle East-North Africa Renewable Energy Conference, 2006.

6. NASA, February 2020. [Online]. Available: https://power.larc.nasa.gov.

7. Sharif, Adel O., Hazim Al-Hussaini, and Ibrahim A. Alenezi., "New method for predicting the performance of solar pond in any sunny part of the world," Sweden, Linköping University Electronic Press, 2011, pp.3702-3709.

8. SIS, "State Information service" 2020. [Online]. Available: http://www.sis.gov.eg. [Accessed 16 January 2020].

9. IRENA, "International Renewable Energy Agency" 2019. [Online]. Available: https://www.irena.org.

10. A. Afify, "Hydro and solar-pond-chimney power scheme for Qattara Depression, Egypt," International Journal of Water Resources and Environmental Engineering, vol. 6(1), No. 2141-6613, pp. 12-18, 2014.

\section{AUTHORS PROFILE}

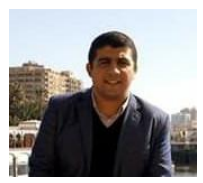

Mohamed Nower Associate Researcher of Irrigation and Hydraulics department of civil Engineering in National Water Research Center (NWRC) in Cairo Egypt. Interested in Energy, management and water sector. Have a special interest in concrete structures. Graduated from Shorouk High Institute, Faculty of Engineering in 2010 Excellent grade with Honor's Degree, 91.07\%, rank = 1/480. Teaching Assistant, Department of Civil Engineering, Shorouk High Institute, Cairo, Egypt. Diploma of the "Hydraulic Engineering in River Basins" with Excellent grade from Hydraulics Research Institute(HRI). Certificate in project management professional from Canadian academy for science \& technology and Brooklyn academy. M.Sc., Faculty of Engineering, Ain Shams University in 2016. Published many of papers in different national and international journal.

Published By:

Blue Eyes Intelligence Engineering

\& Sciences Publication

DOI: 10.35940/ijeat.D7807.049420

Journal Website: www.ijeat.org

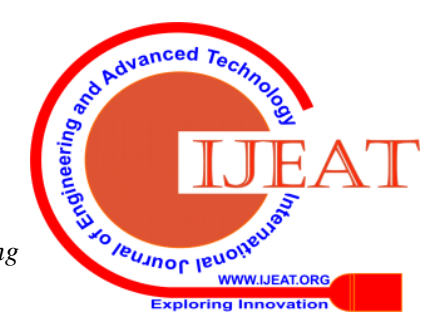


Ashraf Elashaal Professor Emeritus of Dam and Geotechnical Engineering department in National water research center in Cairo Egypt. Interested in Energy and water sector. Have a special interest in concrete structures. Published 45 papers and articles in different national and international journal and conferences. Graduated from Cairo University, Faculty of Engineering in 1979 specialized in foundations resting on Problematic soils and earth reinforcement systems. Through his professional career, Involved in various consulting jobs. His professional experience covers areas such as dam design, dam safety, and dam inspection and rehabilitation in U.S.A, Saudi Arabia, South Soudan, Ethiopia and Egypt, slope stability, piling systems, soil investigations, problematic soils, Irrigation and drainage structures, earth structures, canal lining, seepage control, and erosion protection and infra-structures. Gained a wide experience in utilizing field monitoring and physical and numerical modeling as tools of geotechnical and structural analysis. Special experience in designing special foundation systems like floating- foundation, foundation on expansive, dispersive and collapse soils also, he gained a considerable experience in dealing with foundations for high-rise buildings. Teaching subject of dam engineering in the three-month course titled "Integrated Management of River Basins", in addition to tailormade courses in designing dam and hydraulic structures at the regional training center ministry of water resources and irrigation, Egypt. chairman of the Egyptian National Committee on Large Dams and Barrages. Egypt.

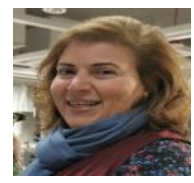

Sonia El-Serafy Professor of Coastal Engineering and Head of the Hydraulics and Engineering Department of Ain Shams University in Cairo Egypt. Interested in shoreline morphology and sediment transport. Have a special interest in concrete structures resistant to chlorides. Published 48 research papers worldwide in the field of Coastal Engineering. Graduated from Ain Shams University, Faculty of Engineering in 1985. Teaching in the same university since then as a teaching assistant, lecturer, assistant professor and professor. Working, as part time in the Arab Academy for Maritime and Transport. Offering consultancy services to private and governmental sectors. Contributing in training of Engineers of the Ministry of Water Resources and Public Works. Offering quality assurance to their publications and reports. Owner to a Scientific Engineering Consultant Office for paraphrasing, editing and translating Engineering books, papers and thesis.

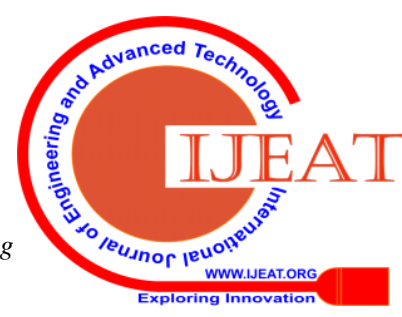

